\title{
Integration of Fuel Cell Micro-CHPs on Low. Voltage Grid: A Danish Case Study.
}

\author{
You, Shi; Marra, Francesco; Træholt, Chresten
}

Published in:

Proceedings of APPEEC

Link to article, DOI:

10.1109/APPEEC.2012.6306951

Publication date:

2012

Link back to DTU Orbit

Citation (APA):

You, S., Marra, F., \& Træholt, C. (2012). Integration of Fuel Cell Micro-CHPs on Low. Voltage Grid: A Danish Case Study. In Proceedings of APPEEC IEEE. https://doi.org/10.1109/APPEEC.2012.6306951

\section{General rights}

Copyright and moral rights for the publications made accessible in the public portal are retained by the authors and/or other copyright owners and it is a condition of accessing publications that users recognise and abide by the legal requirements associated with these rights.

- Users may download and print one copy of any publication from the public portal for the purpose of private study or research.

- You may not further distribute the material or use it for any profit-making activity or commercial gain

- You may freely distribute the URL identifying the publication in the public portal

If you believe that this document breaches copyright please contact us providing details, and we will remove access to the work immediately and investigate your claim 


\section{Integration of Fuel Cell Micro-CHPs on Low Voltage Grid: A Danish Case Study}

\author{
Shi You \\ Department of Electrical Engineering \\ Technical University of Denmark \\ Lyngby, Denmark \\ shyo@elektro.dtu.dk
}

\author{
Francesco Marra, Chresten Træholt \\ Department of Electrical Engineering \\ Technical University of Denmark \\ Lyngby, Denmark \\ ffm, ctr\}@elektro.dtu.dk
}

\begin{abstract}
The future significance of fuel cell (FC) powered micro combined heat and power (micro-CHP) units in meeting the residential energy demands is set to increase, which may have a considerable impact on the low voltage (LV) grid. The objective of this paper is to investigate into the related technical issues using a Danish case study with different penetration levels of uncoordinated FC micro-CHPs. Based on the findings, it is recommended to design grid oriented integration strategies such as Virtual Power Plants (VPPs) for achieving future smart grids with a large roll out of distributed energy resources (DER).
\end{abstract}

Keywords- distributed energy resources; fuel cell; low volatege grid; micro-CHP; Virtual Power Plant

\section{INTRODUCTION}

The concept of micro combined heat and power (microCHP) is known as an extension of the conventional cogeneration technology, which supplies both electricity and heat to residential houses and small commercial buildings. By capturing the "wasted heat", the overall energy efficiency can reach up to $90 \%$. Although there is no consistent definition regarding the term "micro", the definition given by EU Cogeneration Directive is commonly accepted which defines micro-CHP as units up to $50 \mathrm{~kW}$ electrical output [1]. The most popular prime mover technologies applied to micro-CHP applications include internal combustion engines (ICTs), stirling engines and fuel cells (FCs). Amid different prime mover technologies, FC powered micro-CHPs have advantages over the other two in terms of low emission, high power to heat ratio, excellent part load efficiency, as well as less maintenance and quieter operation due to no moving parts. However, the cost-barriers to a large scale adoption of FC powered micro-CHPs remain significant [2].

Denmark, due to its unique position, has become one of the global leaders in renewable energy and smart grid technologies development. In recent years, Danish strategic energy research and development programs have funded research communities and innovative enterprises within FC and hydrogen technologies at more than DKK 100 mill annually, which has developed a preparation-for-market plan for FC powered micro-CHP [3]. Under this context, according to one of the visionary studies presented in [4], 10\% of the house heating in Denmark will be supplied by FC powered micro-CHPs by 2030. Out of total 2.5 million Danish households, a total of 1.2 GW flexible electricity generation capacity will be introduced to the LV network together with an inevitable impact on the Danish power system.

In this work, the related technical impacts were investigated using a typical Danish rural LV grid model with various penetration levels of uncoordinated FC powered micro-CHPs. The effect on voltage variations, transformer loading, power losses etc. are quantified via the hourly based annual power flow analysis performed in DIgSILENT PowerFactory.

In Section II, the current grid code in Denmark for micro generation is briefly reviewed. Section III presents the simulated LV integration impact study, which includes three parts: simulating the electrical feed-in profile of a FC powered micro-CHP under heat-driven mode; modeling a Danish rural $0.4 \mathrm{kV} \mathrm{LV}$ grid and conducting the steady-state power flow analysis. Different from the uncoordinated operation, several Danish grid oriented integration strategies, which are all developed on the basis of Virtual Power Plant (VPP), are presented in section IV. Section V concludes the paper and provides the further scope.

\section{GRID CODE IN DENMARK FOR MICRO GENERATION}

Technical regulations for grid connection, also known as the Danish grid code, deals with connection of electricity generation facilities and consumers to the main transmission and electric supply grids and requires the users of the Danish grid to comply with the grid code. For distributed generators that are connected to the distribution grids with voltages below $100 \mathrm{kV}$, the current Danish grid code maintains three categories which elaborate on the requirements for (a) grid connected wind turbines, (b) electricity-generating facilities of $11 \mathrm{~kW}$ or lower and (c) thermal power station units larger than $11 \mathrm{~kW}$ and smaller than 1.5 MW separately. In Europe, residential applications of micro-CHP are generally sized around 1-6 kWe in order to avoid uneconomic oversizings. As the focus of this study is to investigate the grid impacts introduced by the residential applications of FC powered micro-CHPs which are generally connect to $0.4 \mathrm{kV}$, the regulation category (b) is considered most relevant.

The grid code of Denmark envisaged for electricity generating facilities of $11 \mathrm{~kW}$ or lower includes elaborations of and supplements to the provisions of the European standard EN50438 [5], which defines a set of specific requirements related to connection, protection, power quality, network and 
system stability, operation and maintenance etc. Nominal voltage for the micro generation facilities is designated $230 \mathrm{~V}$ single-phase or 230/400C polyphase, with maximum current up to $16 \mathrm{~A}$ per phase. In addition to fulfill the general metering, over-current protection and earthing requirements, a set of relay protection functions, which can disconnect/stop the micro generators in certain circumstances, are required to be established, as shown in Table I. To ensure the network and system stability, both geographical information and technical information for the new installations have to be provided to the local electric power utility, regardless of single installation or multiple/planned units. Notifications of decommission or replacement are also requested.

TABLE I. REQUIRED RALAY PROCTION ACCORDING TO EN50438

\begin{tabular}{|l|c|c|}
\hline \multicolumn{1}{|c|}{ Relay Type } & Setting Range & Clearance Time \\
\hline Over voltage (stage 2) & $230 \mathrm{~V}+15 \%$ & $0.2 \mathrm{~s}$ \\
\hline Over voltage (stage 1) & $230 \mathrm{~V}+10 \%$ & $40 \mathrm{~s}$ \\
\hline Under voltage (stage 1) & $230 \mathrm{~V}-10 \%$ & $10 \mathrm{~s}$ \\
\hline Over frequency & $53.0 \mathrm{~Hz}$ & $0.2 \mathrm{~s}$ \\
\hline Under frequency & $47.0 \mathrm{~Hz}$ & $0.2 \mathrm{~s}$ \\
\hline Rate of change of frequency & $2.5 \mathrm{~Hz} / \mathrm{s}$ & $0.2 \mathrm{~s}$ \\
\hline
\end{tabular}

Today, the grid connected FC powered micro-CHPs are normally able to fulfill these requirements; however, the voltage tolerance levels, e.g. 5\% rapid change of the nominal value, of public distribution networks, stated by Standard EN 50160 [6] as a reference of the Danish LV grid code, maybe possibly violated when a large amount of distributed generation e.g. micro-CHPs are suddenly positioned. In addition, depending on the amount of micro generators added to a portion of the grid, upgrade of the line conductors and transformer capacity may also have to be properly investigated by the grid operators,.

\section{A CASE STUDY WITH FC POWERED MICRO-CHPS EMBEDDED IN A DANISH LOW VOLTAGE GRID}

In this section, the integration impact on a real Danish rural $\mathrm{LV}$ network equipped with FC powered micro-CHPs is investigated by means of load flow analysis with typical hourly household load profiles in Denmark.

\section{A. Simulating the Electrical Feed-in Profile of FC Powered micro-CHP}

The general design of most FCs is similar except for the electrolyte. When they are applied to micro-CHPs, a schematic representation as shown in Fig.1 is usually used to illustrate the basic principle. As long as the hydrogen rich gas is produced and fed to the FC, through an electrochemical process, the FC generates electricity, water and heat, functioning like a conventional combined heat and power unit.

In Denmark, the FC-powered micro-CHPs which are being heavily developed at present are mainly based on three kinds: Solid Oxide Fuel Cells (SOFC), High Temperature Polymer
Electrolyte Membrane Fuel Cells (HTPEMFC) and Low Temperature Polymer Electrolyte Membrane Fuel Cells (LTPEMFC). Due to the high operating temperatures, the startup time from cold for the first two kinds FC powered microCHPs vary from several hours to tens of minutes. For LTPEMFC based micro-CHP, the start-up time from cold is usually around 1 minute. When the startup is triggered from standby, it generally takes less than one minute for HTPEM and LTPEM powered micro-CHPs, while for the SOFC powered units it could take close to an hour.

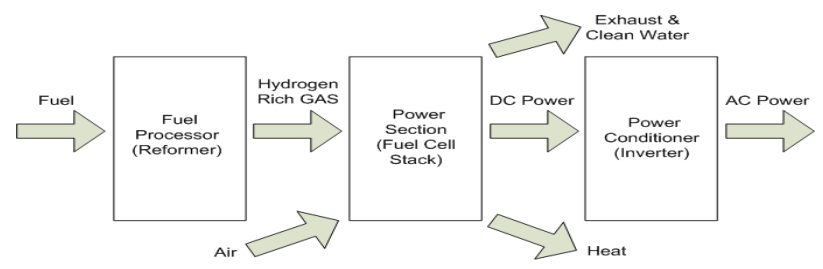

Fig.1 Basic principle of FC powered micro-CHP.

In this study, on the basis of the system characteristics of a SOFC powered micro-CHP system provided by Dantherm Power A/S, a $230 \mathrm{~V} / 50 \mathrm{~Hz}$ FC power micro-CHP is modeled as a $1 \mathrm{kWe}$ power source with a unity power factor and a modulating range $45-100 \%$ Electrical efficiency and thermal efficiency of the system are set as $37.9 \%$ and $44.4 \%$ separately, implying that the maximum thermal out is $1.77 \mathrm{~kW}$. This microCHP system works in heat-led mode, in other words, the thermal production follows the household heat load as much as possible and the electricity is therefore treated as byproduct. As a preliminary study, thermal storage is excluded in this simulation since it is able to increase the flexibility of microCHP performance in many different ways. To limit the number of stops during operation, a minimum off time is set as 24 hours to avoid the frequent starts and stops under low thermal load circumstances.

Hourly-based annual performance of the simulated microCHP is given in Fig. 2 and Fig. 3, where thermal performance and electrical performance are illustrated separately. A typical Danish household generally consumes 13MWh heat and 4.8MWh electricity in a year. For the simulated micro-CHP under heat-led mode, it operates 5136 hours during the year with two stops, and covers the annual household energy requirement by $45.36 \%$ for the heat and $104.86 \%$ for the electricity. This simulated performance is thus very close the measured performance obtained from Dantherm Power A/S.

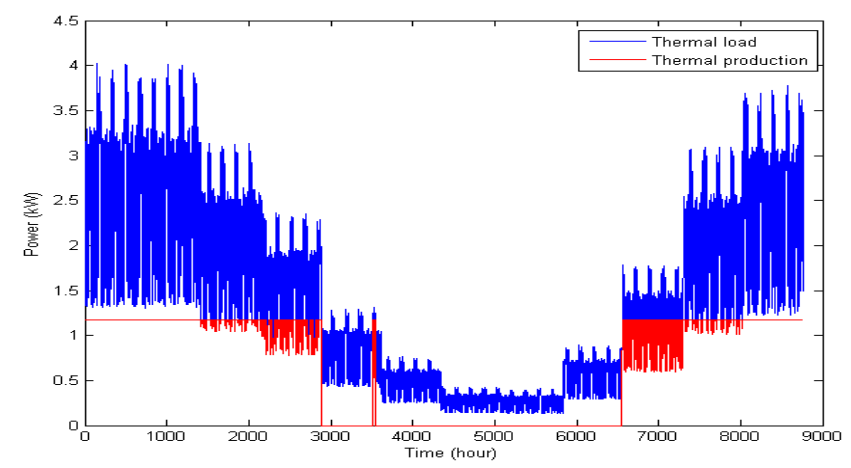

Fig.2 Thermal performance of the simulated FC powered micro-CHP following a typical Danish household thermal load profile. 


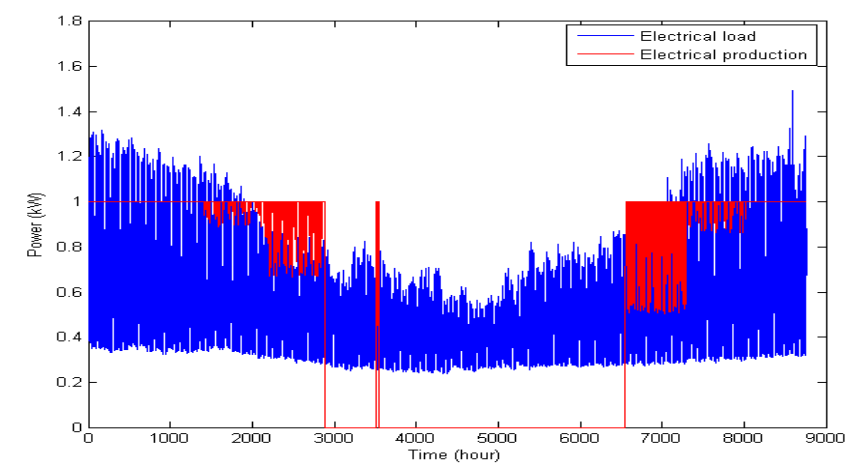

Fig.3 Electrical performance of the simulated FC powered micro-CHP with a typical Danish household electrical load profile.

\section{B. Modeling a residential Danish LV Grid}

The LV grid considered in this study, as depicted in Fig.4, represents a typical radial residential LV network for rural area in Denmark. This secondary feeder is equipped with a 100 $\mathrm{kVA} 10 / 0.4 \mathrm{KV}$ transformer and 17 distribution cabinets to serve a residential area with 44 households. The cable lengths and cross-sections are also considered in the modeling and simulation.

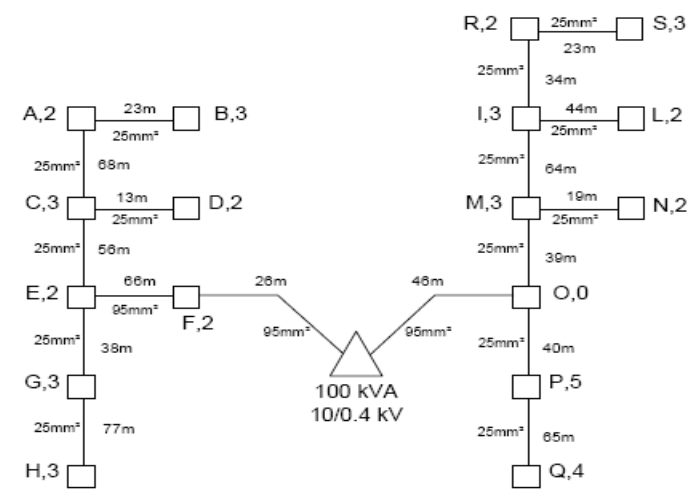

Fig.4 Topology of a residential LV network for rural area in Denmark

The electrical load profiles applied to all households again use the same electrical load profile depicted by the blue line in Fig. 3. In other words, a unity diversity factor is considered in this case, which represents the worst case in terms of the network capacity. The power factor for every household is assumed to 0.95 along the simulation period. The short circuit power of external grid is set as 300MVA with X/R of 10 .

\section{Influnce on the LV Grid}

In this study, micro-CHPs are randomly allocated to the households when their penetration level increases. The integration influence affected by different penetration levels are characterized by a set of indicators, including

- Transformer loadings,

- Voltage magnitudes at both feeder top (secondary side of the transformer) $V_{\text {top }}$ and feeder terminal B (the farthest terminal from the transformer) $V_{\mathrm{B}}$,
- $\quad$ Active power losses associated with both electricity import and electricity export

Results derived from the annual hourly-based power flow analysis are summarized in Table II, Table III and Table IV respectively. Following the increase of micro-CHP penetration level, the transformer loading decreases gradually until the penetration level reaches 50\%. From 50\% and above, both minimum and average values start to increase due to the increasing power injection from the micro-CHPs, while the maximum loading is further reduced to $43.64 \%$ with $100 \%$ penetration. The voltage magnitudes at both feeder top and feeder terminal B are slightly increased along with the penetration increase. With respect to the electricity exchange, the introduction of micro-CHP tremendously reduces the electricity being imported. At 50\% penetration, reverse power flow has been observed for 1579hours within a year; while the number of hours for exporting electricity prolongs to 4679 for the $100 \%$ penetration scenario, resulting 5.25MWh electricity export in the year and an increase of grid losses.

TABLE II. ANNUAL SUMMERY OF TANSFORMER LOADING.

\begin{tabular}{|c|c|c|c|}
\hline \multirow{2}{*}{$\begin{array}{c}\text { Pen. } \\
\text { (\%) }\end{array}$} & \multicolumn{3}{|c|}{ Transformer Loading (\%) } \\
\cline { 2 - 4 } & Min. & Max. & Ave. \\
\hline 0 & 12.08 & 75.58 & 27.51 \\
\hline 25 & 5.85 & 65.35 & 22.09 \\
\hline 50 & 5.61 & 55.70 & 19.04 \\
\hline 75 & 6.90 & 46.88 & 19.78 \\
\hline 100 & 8.74 & 43.64 & 23.18 \\
\hline
\end{tabular}

TABLE III. ANNUAL SUMmery OF VOLTAGE Profile.

\begin{tabular}{|c|c|c|c|c|c|c|}
\hline \multirow{2}{*}{$\begin{array}{c}\text { Pen. } \\
(\%)\end{array}$} & \multicolumn{3}{|c|}{$V_{\text {top }}$ (p.u.) } & \multicolumn{3}{c|}{$V_{\text {B }}$ (p.u.) } \\
\cline { 2 - 7 } & Min. & Max. & Ave. & Min. & Max. & Ave. \\
\hline 0 & 0.9776 & 0.9962 & 0.9914 & 0.9684 & 0.9950 & 0.9886 \\
\hline 25 & 0.9783 & 0.9976 & 0.9925 & 0.9719 & 0.9976 & 0.9905 \\
\hline 50 & 0.9803 & 0.9993 & 0.9936 & 0.9745 & 0.9998 & 0.9919 \\
\hline 75 & 0.9823 & 1.0012 & 0.9947 & 0.9785 & 1.0036 & 0.9941 \\
\hline 100 & 0.9843 & 1.0030 & 0.9957 & 0.9812 & 1.0060 & 0.9955 \\
\hline
\end{tabular}

TABLE IV. ANNUAL SUMMERY OF EXCHANGE AND LOSSES

\begin{tabular}{|c|c|c|c|c|}
\hline Pen. (\%) & $\begin{array}{c}\text { El. Dem. } \\
\text { (MWh) }\end{array}$ & $\begin{array}{c}\text { El. Import } \\
\text { (MWh) }\end{array}$ & $\begin{array}{c}\text { Loss/Dem. } \\
\text { (\%) }\end{array}$ & $\begin{array}{c}\text { Hours for } \\
\text { El. Export }\end{array}$ \\
\hline 0 & 211.20 & 216.84 & 2.67 & 0 \\
\hline 25 & 211.20 & 160.88 & 2.39 & 0 \\
\hline 50 & 211.20 & 105.24 & 2.26 & 1579 \\
\hline 75 & 211.20 & 49.85 & 2.25 & 3852 \\
\hline 100 & 211.20 & -5.25 & 2.38 & 4679 \\
\hline
\end{tabular}

\section{GRID ORIENTED INTERGRATION VIA VRITUAL POWER PLANTS}

Although the current study proves the technical feasibility of having $100 \%$ of FC powered micro-CHP in a Danish LV network, it has to be noted that there is a strong correlation between the penetration level of micro-CHP and the grid performance. Further, due to the relatively low heat demand at summer, the electrical capacity of micro-CHP is not fully explored. To address the grid barriers and to optimally use these resources, the idea of VPP has been widely investigated in Denmark to facilitate the DER integration from both 
technical and economic perspectives [7]. Depending on VPP aggregator's perception, the operation of a massive number of micro-CHPs is coordinated to pursue grid-oriented integration strategies. In this section, three Danish FC powered micro-CHP based paradigms are briefly introduced.

\section{A. Wind Power Balancing}

One idea that is being demonstrated in Denmark is to use FC powered micro-CHPs to balance the wind production. In the so called "Lolland Hydrogen Community", as depicted in Fig. 5, the excessive wind is electrolyzed to produce hydrogen to feed the FC powered micro-CHPs [8].

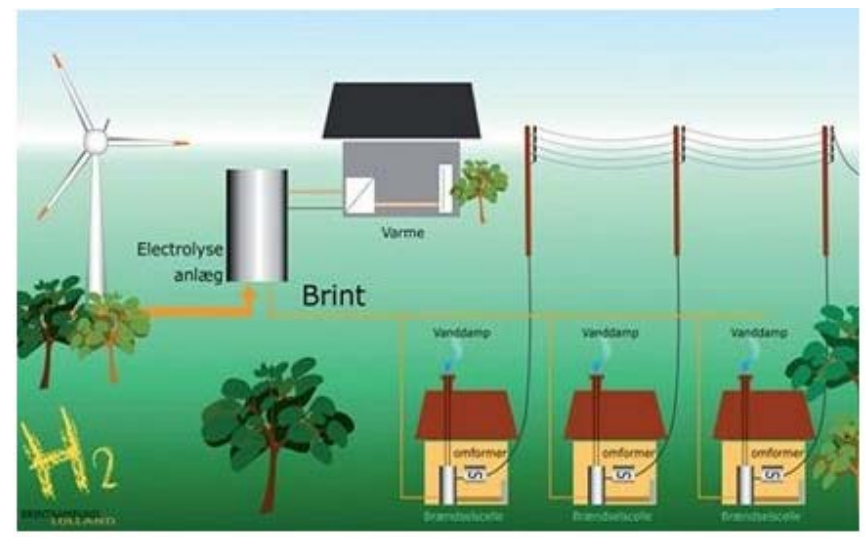

Fig.5 Visionary picture of a Danish hydrogen-powered community

\section{B. Facilitation of the Eelectric Vechicles Intergration}

In addition to balance the wind power, the FC powered micro CHPs also have the potential to facilitate the integration of electric vehicles (EVs). One of the recent studies [9] have unveiled the technical barriers in the Danish LV grid for EV integration, stating the LV transformer would be overloaded when $30 \% \mathrm{EV}$ penetration is expected. As the FC powered micro-CHPs are also connected to the $\mathrm{LV}$, it is possible that the micro-CHP integration could counteract the effects of EV integration and help improve the EV penetration. However, to realize this, the head-led operation mode for micro-CHP has to be replaced by coordinated operation strategies since the summer stops of micro-CHPs provide no contribution to the EV integration.

\section{Voltage Regulation}

The Danish Cell project [10], run by the Danish TSO Energinet.dk, aims to adapt the Danish power system to future requirements by increasing the extent of system control and monitoring. By granting cell controller the access to the IEC61850 based FC inverters, the FC powered micro-CHPs can be controlled by the cell controller to provide voltage regulation when it is necessary. In reciprocation, the microCHP owners get economic rewards and reliable electrical supply.

\section{CONCLUSION}

The FC powered micro-CHP is an interesting and useful addition for future energy conversion mixes. Although the present economics considering the use of FC powered microCHPs will prevent a large-scale spreading in the next few years, understanding the technology and getting the electrical grid prepared for the associated challenges are very import to the system operators.

.In this study, the related technical impacts on the LV grid is investigated using a residential $\mathrm{LV}$ network model for rural area in Denmark. When FC powered micro-CHPs are deployed in the LV network under heat-led mode, $100 \%$ penetration is quite feasible due to the fairly small size of the unit. Even though, a high correlation between the grid performance and the micro-CHP penetration level can be easily found. For instance, the grid losses start to increase rather than to decrease when the penetration level reaches a quite high value.

In the future, grid oriented integration strategies offered by different VPPs would be able to manage the DER alike assets in a more optimal way. FC powered CHPs can thus either be grouped alone or be aggregated together with other DERs to provide various grid supporting services. Several of these possibilities which are being investigated in Denmark are briefly introduced in this paper. Extensions of the study to account for larger distribution systems, detailed models for FC powered micro-CHPs, optimized coordination schemes etc. are under current investigation.

\section{REFERENCES}

[1] EU Directive 2004/8/CE, Official Journal of the European Union, 2004

[2] L. M. Chamra and P. J. Mago, Micro-CHP Power Generation for Residential and Small Commercial Buildings. Nova Science Pub Inc, 2009.

[3] Energinet.dk, Annual report on Danish research programmes, pp. 6781, June, 2011

[4] H. Lund and B. V. Mathiesen, "Energy system analysis of $100 \%$ renewable energy systems- The case of Denmark in years 2030 and 2050,” Energy, vol. 34, pp. 524-531, 2009

[5] Energitnet.dk, Technical regulation for electricity-generating facilities of $11 \mathrm{~kW}$ of lower, June, 2008

[6] Standard EN 50160, "Voltage characteristics of electrcity supplied by public distribution networks," Cenelec 2010

[7] S. You, C. Træholt and B. Poulsen, "Generic virtual power plants: management of distributed energy resources under liberalized electricity market," Proceedings of APSCOM, Hong Kong, 2009, pp. 1-6.

[8] H. Iskov, "Micro CHP with integrated elecktrolyzer and gas storage 2005-2007”, IEA/HIA Case Studies, 2009

[9] F. Marra, M. M. Jensen, "Power quality issues into a Danish LV grid with electric vehicles," to be published in the proceedings of IEEE EPQU, Lisbon, 2011

[10] P. Lund, “The Danish cell project - part 1: background and general approach,” PESGM, Tampa, 2007, pp. 1-6 